\title{
The Effort for Decreasing the Rate of Stunting Through Early Childhood Health and Nutrition Training for Tutors/Parents of Early Childhood Education
}

\author{
Yenina Akmal' ${ }^{1}$ Hikmah $^{2}$, Ika Subekti ${ }^{3}$, Ichtineza Halida Hardono ${ }^{4}$ \\ Early Childhood Teacher Education, State University of Jakarta \\ DOI: $10.31004 /$ obsesi.v4i1.302
}

\begin{abstract}
Stunting also occurs in urban areas, i.e., DKI Jakarta. East Jakarta is the second-highest (25.7\%) location where stunting occurred. Since this activity was conducted in Duren Sawit Subdistrict, where numerous people still received Healthy Jakarta Cards, special efforts were needed to reduce the high stunting rate. The method used is qualitative descriptive. The form of training is the participant observation method and demonstration, include cooking demonstrations and Focus Group Discussion (FGD). This efforts made to decrease the number of Stunting in Duren Sawit Subdistrict. The training was given to \pm 35 ECE tutors and parents of students from various ECE in Duren Sawit Subdistrict. Tutors and parents seemed enthusiastic and active during the activities, especially when they were given the task to create a one-week healthy menu in groups and then closed with a demo of making a cake with purple sweet potato as ingredients.
\end{abstract}

Keywords: nutrition; stunting; ece tutors; parenting

\begin{abstract}
Abstrak
Stunting tidak hanya terjadi di pedesaan, stunting juga terjadi di perkotaan, seperti di DKI Jakarta. Jakarta Timur merupakan wilayah tertinggi kedua di DKI Jakarta dengan kasus stunting (25,7\%). Kegiatan ini dilakukan di Kecamatan Duren Sawit dimana banyak masyarakatnya masih menerima Kartu Jakarta Sehat (KJS). Metode yang digunakan yaitu metode deskriptif kualitatif. Bentuk Pelatihan adalah dengan metode observasi partisipan serta demonstrasi, termasuk Demo memasak maupun Focus Group Discussion (FGD). Upaya ini dilakukan untuk menurunkan angka Stunting di Kecamatan Duren Sawit. Pelatihan diberikan kepada \pm 35 tutor maupun orang tua murid dari berbagai PAUD di Kecamatan Duren Sawit. Tutor dan orang tua murid yang menjadi peserta pelatihan terlihat antusias dan aktif selama mengikuti kegiatan. Terlebih lagi ketika diberikan tugas untuk membuat menu sehat selama seminggu secara berkelompok serta ditutup dengan demo membuat kue basah dengan bahan ubi ungu.
\end{abstract}

Kata Kunci: nutrisi; stunting; tutor PAUD; parenting

Copyright (c) 2019 Yenina Akmal, Hikmah, Ika Subekti, Ichtineza Halida Hardono

$\triangle$ Corresponding author :

Email Address : yenina.akmal@yahoo.com (Rawamangun, Jakarta)

Received 13 October 2019, Accepted 30 November 2019, Published 22 December 2019 


\section{INTRODUCTION}

The Indonesian Human Development Index (HDI) in 2017 ranked 116 out of 180 countries in the World (UNDP, 2018), down three from the previous year. HDI assessment indicators consist of economic, education, and health aspects. The health sector, with various problems such as stunting, infectious diseases, non-communicable diseases, and others, is still a priority that continues to be improved in Indonesia.

Stunting is the failure of growth and development of a child under five years old (toddlers) caused by chronic malnutrition and infection, especially in the first 1,000 days of life (TNP2K, 2018). Reference from Departemen Kesehatan, even though in 2018 the percentage of stunting in Indonesia decreased from $37.2 \%$ to $30.8 \%$, this number was nevertheless higher than the WHO recommendation $(20 \%)$. Based on the results of Nutritional Status Monitoring conducted by the Indonesian Ministry of Health in 2017, around $29.6 \%$ of toddlers in Indonesia belonged in short and very short categories. This number was included in the high category when compared to neighboring countries such as Myanmar (29\%), Sri Lanka (17\%), Thailand (10\%), and others (Kementerian Kesehatan RI, 2018).

Meanwhile, reference of Kemenpppa, the data from Statistics Indonesia in 2015 showed that the number of early childhood (0-8 years) was 39,656,000. The data shows how large the number of early childhood in our country(Kementerian Pemberdayaan Perempuan dan Perlindungan Anak, 2018). However, (BPS, 2019) showed data in 2019 that \pm 25.14 million $(9.41 \%)$ of Indonesia's population lives below the poverty line. Low levels of education (averaged junior high school) surely have an impact on the level of early childhood health. The latest data in 2015 showed that the maternal mortality rate was quite high, around 305/100,000 births and the infant mortality rate in 2016 was around 25.5/1000 births. These conditions undoubtedly have an impact on early childhood development programs, where children need good nutrition and proper care and nurture so they can grow into a high-quality generation.

Stunting itself can be caused by various aspects, including the parental nutrition understanding, family financial factors (Chirande et al., 2015), culture, healthy habits (Mbuya \& Humphrey, 2016) and inaccurate care and nurture. The effect of these things can make a child inevitably get an infection that results in stunting. Esfarjani added other things that could lead to the appearance of stunting, such as diet, parental nutrition awareness, economic level, parental education, and parental care and nurture(Esfarjani, Roustaee, Mohammadi-Nasrabadi, \& Esmaillzadeh, 2013). Parents are the main and first environment for children. It is in line with what was stated by a Russian psychologist, Vygotsky, that parents have an essential role in the growth of their children. The meaning of parent and family involvement in childcare which involves six types viz.; parenting, communicating, volunteering, learning at home, decision making, and cooperating in the community.

Reference of (Campbell, Pungello, Miller-Johnson, Burchinal, \& Ramey, 2001), nurturing, caring for, and educating early childhood is a full-time and very challenging job but gives rewards and surprises. These things are challenging for parents and every family, bringing great interest and fascinating, there is even a desire to continuously want to nurture and observe the growth and development of abilities and skills of early childhood in general. The process of child development should run naturally. Children will grow vertically (quantitatively) which can be seen through size, weight, body length, and more. On the contrary, horizontal (developmental) growth is qualitative that cannot be measured but can be seen and felt through everyday attitudes and behavior. The indicators above show that full attention to the improvement of Indonesia's human resources, which must be started at an early age, is really important.

Stunting does not only occur in rural areas but also occurs in urban areas, such as in West Java, East Java, DKI Jakarta, and Bali. The DKI Jakarta Health Office stated that in 2017, the condition of infants with malnutrition increased to $2.92 \%$. In DKI Jakarta, stunting 
occurred in infants aged 0-59 months is reaching 22.7\% (Kementerian Kesehatan RI, 2018) with the highest cases in Central Jakarta at $29.2 \%$ and the second-highest at East Jakarta at $25.7 \%$. This number shows that DKI Jakarta is categorized as acute chronic because it is above the WHO limit of $20 \%$.

East Jakarta had a population of 2,892,783 people with a high average population density of 14,854 people/ $\mathrm{km}^{2}$ (Suku Dinas Jakara Timur, 2015). This activity was carried out in Duren Sawit Subdistrict. This subdistrict has a population of 392,961 people with a density of 17,349 people $/ \mathrm{km}^{2}$, which is the second largest in the East Jakarta region. With the high percentage of stunting and population density, some action is needed to reduce this percentage. In this subdistrict, there are numerous people who received the Jakarta Health Card. It shows that there is still a necessity for special efforts to reduce the high stunting rate, one of which is to increase activities that can be directly felt by the community.

\section{METHOD}

Efforts were made in the form of Health and Nutrition Training, conducted in Duren Sawit Village, Duren Sawit Subdistrict in June 2019, with \pm 35 participants consisting of mothers, parents, and ECE tutors and managers. The method used is qualitative descriptive. The form of training is the participant observation method (Jorgensen, 2015) and demonstration (Purwati, 2015). With this method, participants are expected to be actively involved directly in cooking demonstrations and Focus Group Discussion (FGD) (Afiyanti, 2008).

The material from the training was Healthy Habits(Jayanti, Effendi, \& Sukandar, 2011). This material gave a demo of how to wash hands properly with practice simultaneously. Additionally, there was material on Early Childhood Health and Early Childhood Development Stages. Ended with the performance of making cakes from purple sweet potatoes. It is expected that after attending the Health and Nutrition Training, parents of students will be able to know, to understand and to apply in their daily basis.

\section{RESULT \& DISCUSSION}

Stunting or failure to thrive can occur in a variety of social classes; educated or uneducated, economically strong or weak. Because the main point is the efforts made by parents to make the food consumed by their children is proper with their daily needs and a maintained clean and healthy lifestyle which becomes a character so that they can be called a healthy family.Stunting is often insensible by families living in areas that generally have short stature, even among health workers. Stunting does not receive the same attention as thin weight, especially if the height is not routinely measured as part of the public health program. Many families, health workers, and policymakers are not aware of the consequences of stunting that they cannot be considered as a public health problem.

The knowledge about health and diet (choosing, processing, serving) are needed to achieve a healthy family, notably if early childhood still exists in the family. It will affect the growth process of early childhood. Growing means that something can be measured and calculated like weight. While developing qualitatively, cannot be measured but can be seen in children's daily habits such as happiness, whiny, zealous, weak, quiet, agile, and so on.

Coaching or workshop about the strategy to reduce stunting rates through the Health and Nutrition Training was a series of training conducted in several stages in Duren Sawit Subdistrict in August with \pm 35 participants of ECE tutors and parents of students from various ECE. The training was dicvided into several stages, started with the provision of material about The Strategy for Reducing Stunting Rates through Health and Nutrition Training. After the materialpresentation, along with questions and answers session were done, the training continued to form discussion 


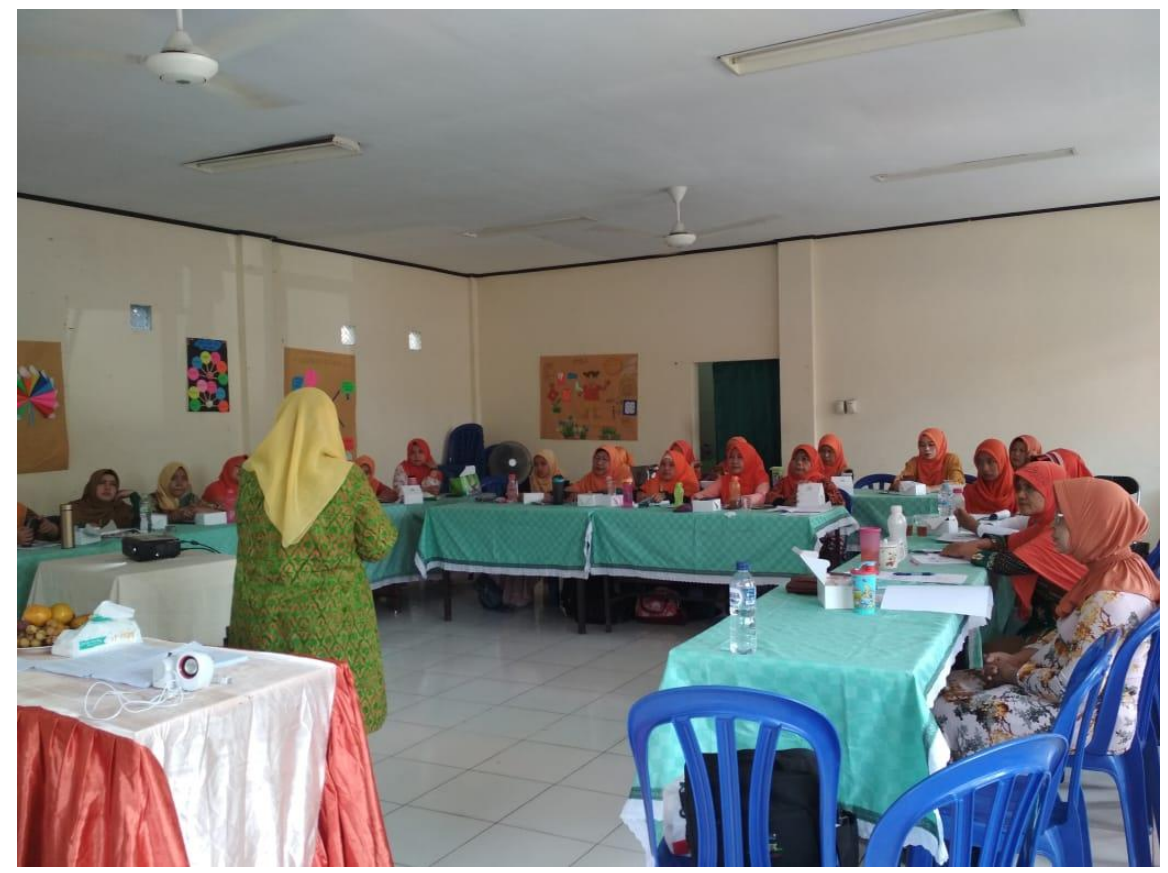

Fig 1. Sharing Session groups to conduct a Focus Group Discussion (FGD) for designing a Oneweek.

Healthy Menufor Early Childhood. Then the representatives of each group presented and received some suggestion from other groups. In the end, each participant could carry home the One-week Healthy Menu for Early Childhood.The next activity is the Healthy Habits practice, i.e., the right way to wash hands whereby the participants seemed very enthusiastic. Toilet Training and Balanced nutrition were also explained in thissession. The last pursuit was in groups consisting of five people.

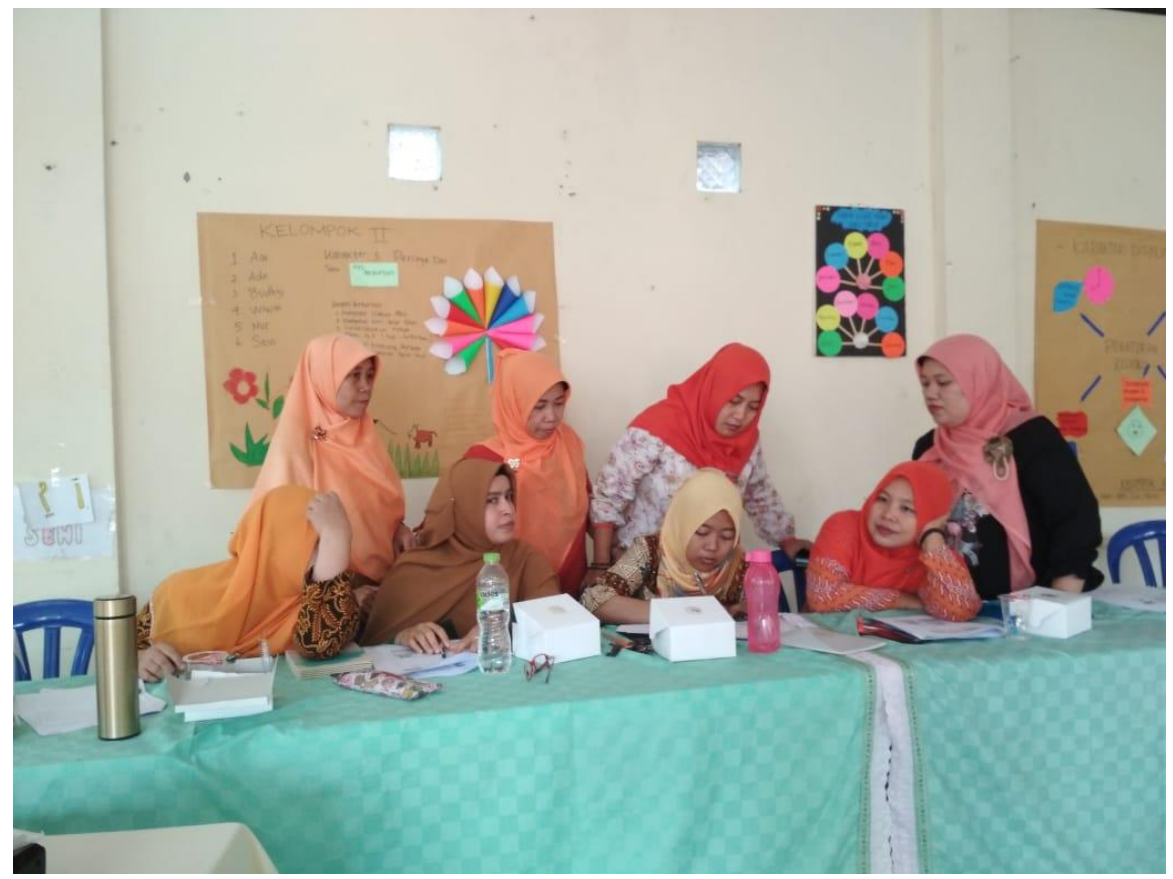

Fig 2. FGD Session

It was a demonstration of making banana cakes made from purple sweet potato and horn banana.Keep in mind that purple sweet potatoes contain carbohydrate. 


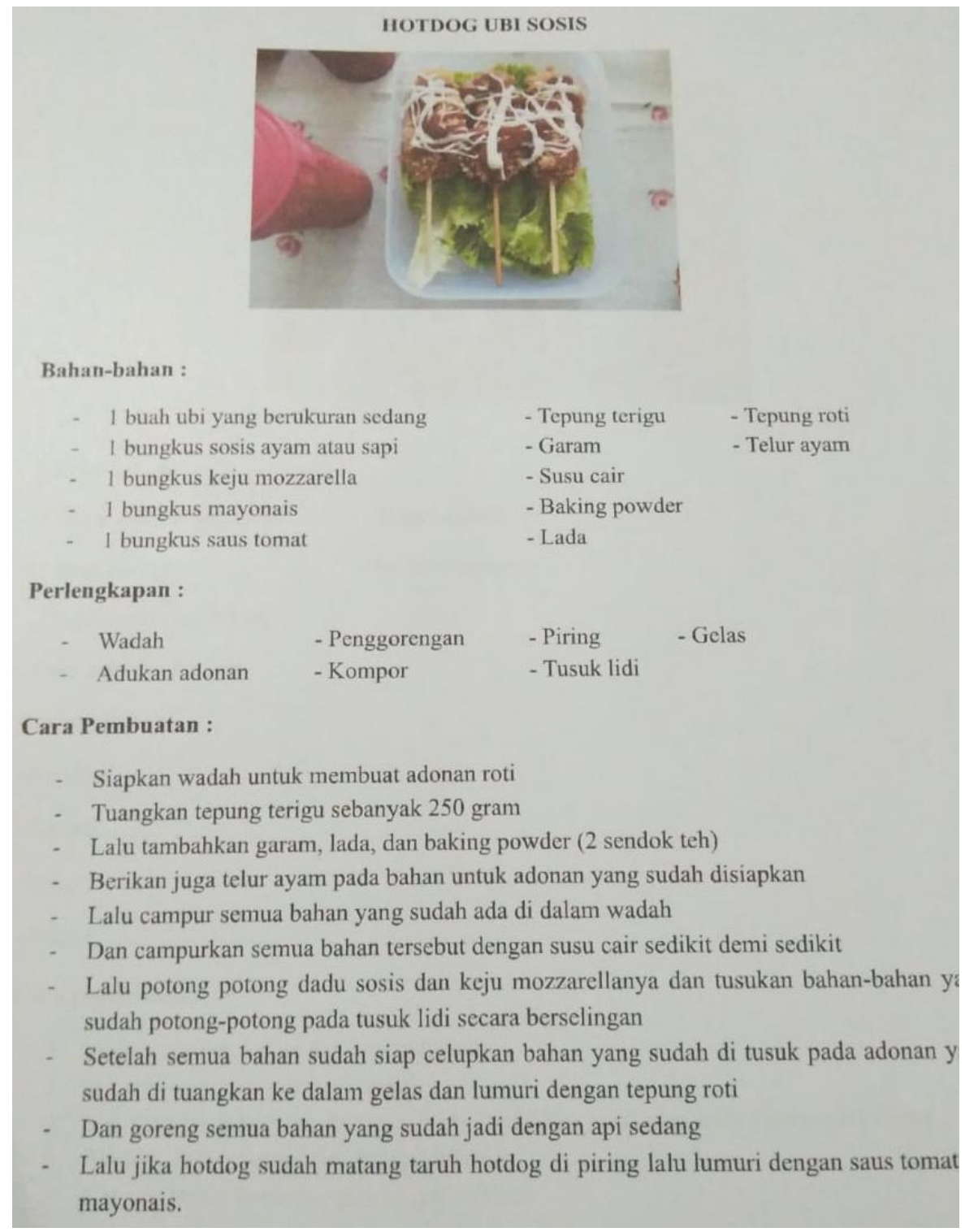

Fig 3. The Example of Healthy Food

substances that are rich in vitamins(Irpan, Sundawa, \& Fahmiawati, 2017; Widowati, 2010; Zuraida \& Supriati, 2001) so it is good for the growth of the body of early childhood. Participants were very excited to follow it and were happy when they could bring home their product.

\section{CONCLUSION}

The efforts to reduce stunting rates in East Jakarta, which are above the WHO limit number, must be immediately executed because there is a significant relationship between economic, nutritional knowledge of young parents with care and nurture patterns and the dietary and healthy habits that result in stunting. These efforts must be implemented by all parties viz., parents, ECE tutors, and regional governments because this has become a joint task that must be resolved immediately.

\section{ACKNOWLEDGMENT}

Many gratitude to Allah SWT who has given easiness in the making process of this paper. The researcher also would say many thanks to Tutors and parents seemed in PAUD Duren Sawit Jakarta for helping and facilitating the research process. In addition, I thank the editor team of Obsesi journal for enabling this journal to be ready to publish 


\section{REFERENCES}

Afiyanti, Y. (2008). Focus Group Discussion (Diskusi Kelompok Terfokus) sebagai Metode Pengumpulan Data Penelitian Kualitatif. Jurnal Keperawatan Indonesia, 12(1), 58-62. https://doi.org/10.7454/jki.v12i1.201

BPS. (2019). STATISTIK Profil Kemiskinan di Indonesia.

Campbell, F. A., Pungello, E. P., Miller-Johnson, S., Burchinal, M., \& Ramey, C. T. (2001). The development of cognitive and academic abilities: growth curves from an early childhood educational experiment. Developmental Psychology, 37(2), 231-242. https://doi.org/10.1037/0012-1649.37.2.231

Chirande, L., Charwe, D., Mbwana, H., Victor, R., Kimboka, S., Issaka, A. I., ... Agho, K. E. (2015). Determinants of stunting and severe stunting among under-fives in Tanzania: Evidence from the 2010 cross-sectional household survey. BMC Pediatrics, 15(1), 1-13. https://doi.org/10.1186/s12887-015-0482-9

Esfarjani, F., Roustaee, R., Mohammadi-Nasrabadi, F., \& Esmaillzadeh, A. (2013). Major dietary patterns in relation to stunting among children in Tehran, Iran. Journal of Health, Population and Nutrition, 31(2), 202-210. https://doi.org/10.3329/jhpn.v31i2.16384

Irpan, A., Sundawa, E., \& Fahmiawati, N. A. (2017). GERUBI (Burger Ubi) Inovasi Pangan Lokal Sebagai Alternatif Makanan Pokok yang Kaya Akan Gizi. Jurnal Program Mahasiswa Kreatif, 1(1), 1-6.

Jayanti, L. D., Effendi, Y. H., \& Sukandar, D. (2011). Perilaku Hidup Bersih Dan Sehat (Phbs) Serta Perilaku Gizi Seimbang Ibu Kaitannya Dengan Status Gizi Dan Kesehatan Balita Di Kabupaten Bojonegoro, Jawa Timur. Jurnal Gizi Dan Pangan, 6(3), 192. https://doi.org/10.25182/jgp.2011.6.3.192-199

Jorgensen, D. L. (2015). Participant Observation. Emerging Trends in the Social and Behavior Sciences, 1-15. https:// doi.org/10.1002/9781118900772.etrds0247.

Kementerian Kesehatan RI. (2018). Buku saku pemantauan status gizi. Buku Saku Pemantauan Status Gizi Tahun 2017, 7-11.

Kementerian Pemberdayaan Perempuan dan Perlindungan Anak. (2018). Profil Anak Indonesia 2018. Ilmu Pendidikan, 5(1), 1-378.

Mbuya, M. N. N., \& Humphrey, J. H. (2016). Preventing environmental enteric dysfunction through improved water, sanitation and hygiene: An opportunity for stunting reduction in developing countries. Maternal and Child Nutrition, 12, 106-120. https://doi.org/10.1111/mcn.12220

Purwati, E. (2015). Meningkatkan Keterampilan Membuat Peyek Rinuak Melalui Metode Demonstrasi Pada Anak Tunagrahita Ringan. E-JUPEKhu, 4(1), 72-84.

Suku Dinas Jakara Timur. (2015). Profil Kesehatan Jakarta Timur.

TNP2K. (2018). Strategi Nasional Percepatan Pencegahan Anak Kerdil (Stunting) Periode 2018 2024.

UNDP. (2018). Human Development Indices and Indicators. 2018 Statistical Update. United Nations Development Programme, 27(4), 123. Retrieved from http://hdr.undp.org/sites/default/files/2018_human_development_statistical_upd ate.pdf\%0Ahttp://www.hdr.undp.org/sites/default/files/2018_human_developme nt_statistical_update.pdf\%0Ahttp://hdr.undp.org/en/2018-update

Widowati, S. (2010). Diversifikasi Konsumsi Pangan Berbasis Ubi Jalar. Jurnal Pangan, 20(1), 49-61.

Zuraida, N., \& Supriati, Y. (2001). Usahatani Ubi Jalar sebagai Bahan Pangan Alternatif dan Diversifikasi Sumber Karbohidrat. Buletin AgroBio, 4(1), 13-23. 